\title{
Parodontális vertikális csontdefektusok gyógyulásának hosszú távú kiértékelése PRG- vagy EMD-vel történt kezelést követően
} Esetsorozat

\author{
DR. CSIFÓ-NAGY BORÓKA*, DR. SÓLYOM ELEONÓRA*, DR. HUSZÁR TAMÁS**, DR. DŐRI FERENC*
}

\begin{abstract}
A retrospektív esetsorozat célja intraosszeális csontdefektusok gyógyulásának hosszú távú klinikai értékelése autológ vérlemezkében gazdag készítménnyel (Platelet-Rich Gel, PRG) vagy zománc-mátrix derivátummal (Enamel Matrix Derivatives, EMD) történt kezelést követően.

A vizsgálatban 24 intraosszeális defektussal rendelkező, nem dohányzó, krónikus parodontitisben szenvedő páciens vett részt. A négy bemutatott eset ezen kontrollált klinikai vizsgálat résztvevője, akiknél 1, 3, illetve 7 évvel a mútétet követően történt kiértékelés a következő paraméterek rögzítésével: szondázási mélység (PD - probing depth), illetve klinikai tapadási szint (CAL - clinical attachment level). Teljes vastagságú lebenyek képzését követően a defektus kürettálása, illetve gyökérsimítás történt. Vérlemezkében gazdag plazma (PRP) preparálása után, Ca-glükonát és friss vénás vér hozzáadásával vérlemezkében gazdag plazma gél (PRG) készült. A parodontális vertikális defektusok ellátását PRG $(n=2)$ vagy $\operatorname{EMD}(n=2)$ applikációját követően sebzárás követte.

Egy évvel a mútét után mindkét kezelési módszer szignifikáns szondázási mélység (PD) csökkenést és klinikai tapadási nívó (CAL) növekedést eredményezett, és ezek az eredmények 3, illetve 7 év után is kedvezőek maradtak. Bemutatott eseteinknél, úgy a PRG-, mint az EMD-kezelés megbízható hosszú távú klinikai eredményeket mutatott.
\end{abstract}

Kulcsszavak: vertikális csontdefektus, vérlemezke-koncentrátum, zománc-mátrix derivátumok, regeneráció, hosszú távú követés

\section{Bevezetés}

A teljes körú parodontális kezelés célja a gyulladás megszüntetése, a fogágy további pusztulásának megállítása és a parodontális szövetek funkcionális regenerációjának elösegítése [7]. A zománc-mátrix derivátumok (EMD), mint biológiai mediátorok, kémiai barrierként játszanak szerepet a parodontális regenerációban és gyógyulásban. Követéses klinikai vizsgálatok adatai alapján, mély parodontális intraosszeális defektusok zománc-mátrix derivátumokkal történt kezelését követően szignifikáns klinikai tapadásnövekedés és csontos telődés tapasztalható $[9,10]$.

In vitro kutatások igazolták az EMD gyökérhártya és gingivális eredetű fibroblastokra, valamint osteoblastokra kifejtett hatását. Laboratóriumi vizsgálatok során megfigyelték, hogy az EMD az epitheliális sejtekével ellentétben, elősegíti a gyökérhártya eredetű fibroblast sejtek (PDL-F) proliferációját, valamint fokozza a PDLfibroblastok fehérjeszintézisét, illetve elősegíti az általuk kialakított mineralizált gócok megjelenését is. Az EMD elősegíti a mezenchimális sejtek növekedését, ugyanakkor fokozza az autokrin növekedési faktorok kibocsátását a gyökérhártya eredetű fibroblastokból [14].
A kémiai-biológiai faktorok parodontológiai alkalmazásának újabb lehetőségét az autológ növekedési faktorok és a humán rekombináns növekedési és differenciációs faktorok teremtik meg (Platelet-Rich Plasma PRP, Platelet-Rich Gel - PRG, Platelet-Rich Fibrin - PRF, recombinant Growth Factors - rGF's).

A vérlemezkében gazdag plazma (PRP) használata a thrombocyta-koncentrátumból felszabaduló növekedési faktorok gyógyulására és szövetregenerációra gyakorolt hatására alapoz [2]. A sebgyógyulás elősegítésének szempontjából, a felszabaduló növekedési faktorok (GF's) hatásának felerősítése, mely meggyorsíthatja a csontdefektusok gyógyulását és a parodontális regenerációt, nagy jelentőséggel bír. Ennek legegyszerübb módja a thrombocyta eredetű növekedési faktorok lokális kibocsátásának aktivációja, amelyek szinte az összes sebgyógyulási folyamat általános elindítói. Több mint két évtizede dolgozták ki az autológ vérlemezkekoncentrátumok (autológ vérlemezkében gazdag plazma - PRP) intraorális alkalmazásának módszerét [3, 11, 12]. A PRP egy autológ, a vérben található vérlemezkeszám 4-5-szörösét tartalmazó készítmény, mely parodontális csontdefektusokra kifejtett pozitív hatását az osteoblastokra gyakorolt proliferatív és differenciációs, illetve an- 
giogenetikus hatásának köszönheti [19]. A PRP folyékony halmazállapotú, így parodontális defektusok ellátásához vivőanyaggal történő kombinációja szükséges. A vivőanyag használatának elkerülése érdekében a PRP további módosítása lehetővé tette a thrombocyta-koncentrátumok gél állagúvá alakítását (PRG), ezáltal lehetségessé vált parodontális defektusokba történő direkt applikációjuk [4].

A zománc-mátrix derivátumok mint nem humán eredetű biológiai mediátorok (Emdogain ${ }^{\circledR}$, Straumann ${ }^{\circledR}$, Basel, Switzerland) kutatása és alkalmazása a parodontális regeneratív sebészetben, bár több mint két és fél évtizedes múltra tekint vissza, még számos megválaszolatlan vagy nem egyértelmúen megválaszolt kérdést vet fel.

Az autológ növekedési és differenciációs faktorok, valamint a rekombináns növekedési faktorokmint biológiai mediátorok parodontális regeneratív eljárásokban való használatának elméleti és gyakorlati kutatása viszonylag rövidebb múlttal rendelkezik, és számos további vizsgálódási lehetőséget kínál.

A kontrollált klinikai tanulmány a humán autológ növekedési és differenciációs faktorok parodontális regenerációban játszott szerepét vizsgálta. Jelen retrospektív esetsorozat bemutatásának célja parodontális vertikális csontdefektusok gyógyulásának hosszú távú klinikai és radiológiai értékelése autológ vérlemezkében gazdag készítménnyel (PRG), illetve zománc-mátrix derivátummal (EMD) történt kezelést követően.

\section{Vizsgálati anyag és módszer}

A randomizált kontrollált klinikai vizsgálatot a Semmelweis Egyetem Parodontológiai Klinikáján végezték, 24 nem dohányzó, krónikus parodontitisben szenvedő, és vertikális parodontális defektussal rendelkező páciens bevonásával. Egy évvel mútét után az eredmények kiértékelését mind a 24 páciensnél elvégezték, a műtét után három évvel az eredmények hosszútávú értékeléséhez 22 páciens bevonására volt lehetőség.Vizsgált fő paraméterek: klinikai szondázási mélység (PD), klinikai tapadási szint (CAL), valamint röntgenfelvételek készítése „Iong cone” technikával sebészi beavatkozás előtt, majd mútétet követően 1 , illetve 3 évvel $[4,5]$. A jelen vizsgálatban szereplő 4 esetnél 7 év elteltével is tudtunk klinikai és radiológiai kiértékelést végezni.

A sebészi beavatkozás során teljes vastagságú lebenypreparálásra, kürettre, valamint gyökérsimításra került sor.

A tesztcsoportnál ezt követően vérlemezkében gazdag gél preparálása, majd a defektusba történő behelyezése következett.

A gél előállítását vérlemezkében gazdag plazma (PRP) preparálása előzte meg (PRP Soft Start Protocol, Glotech Co. Ltd., Korea). Vérlemezkében gazdag gél előállításának érdekében a PRP-hez Ca-glükonát oldatot, illetve friss, protrombint tartalmazó, autológ vénás vért adtak. 8-10 percen belül bekövetkezett a gélképződés (PRG) [4]. (Kép 1.)
A kontrollcsoportnál a megtisztított gyökérfelszín kondicionálását követően (24\% EDTA - PrefGel ${ }^{\circledR}$, Straumann ${ }^{\circledR}$, Basel, Switzerland), az EMD (Emdogain ${ }^{\circledR}$ ) applikációjára került sor. Sebzárást követően a páciensek posztoperatív szisztémás antibiotikum terápiában és kémiai plakk-kontrollban részesültek.

\section{Eredmények}

A randomizált kontrollált klinikai vizsgálat során az eredményeket a sebészi beavatkozást követő első és harmadik évben értékelték ki. A vizsgált fő paraméterek, a klinikai szondázási mélység (PD), illetve a klinikai tapadási szint (CAL), egy év elteltével mindkét csoport esetében szignifikáns javulást mutattak [4]. A teszt- és kontrollcsoportnál elért eredmények között szignifikáns különbség nem mutatkozott. A hároméves hosszú távú kiértékelések a vizsgált paraméterek tekintetében szignifikáns eltérést nem mutattak az első évben rögzített eredményekhez képest [5]. Az elért eredmények mindkét csoport esetében hosszú távon fenntarthatóak voltak. Hét év elteltével a vizsgálatban részt vett 24 főből csoportonként 2-2 fő vizsgálatára adódott lehetőség. A tesztcsoportba tartozó első páciensnél (PRG 1) a PD értéke a kiindulási $9 \mathrm{~mm}$-ről $5 \mathrm{~mm}$-re csökkent, a $\mathrm{CAL}$ értéke pedig 10-ről $5 \mathrm{~mm}$-re változott 7 év elteltével, a PRG 2 páciensnél mindkét paramétert illetően az értékek $10 \mathrm{~mm}$-ről $6 \mathrm{~mm}$-re változtak. A kontrollcsoportba tartozó két személynél is szignifikáns javulás mutatkozott, az EMD 1 páciens esetében a PD értéke 11-ről $3 \mathrm{~mm}$-re csökkent, míg a CAL értéke 11-ről $5 \mathrm{~mm}$-re változott 7 év elteltével, a EMD 2 páciensnél 9-ről 4 mm-re redukálódott a $\mathrm{PD}$, illetve 11-ről $4 \mathrm{~mm}$-re javult a $\mathrm{CAL}$ érték.

A klinikai követéses vizsgálat eredményeit a radiológiai leletek is alátámasztják. (Kép 2-3.)

\section{Megbeszélés}

A mútétet követő első évben a tanulmány összes résztvevőjénél mindkét módszer esetébenszignifikáns szondázási mélység csökkenést és klinikai tapadásszint növekedést tapasztaltak [4]. A hosszú távú, hároméves kiértékelés az elért pozitív eredmények stabilitásáról tanúskodott [5]. Hét évvel a regeneratív célzatú beavatkozást követően a tanulmányozott populációból csoportonként 2-2 fő vizsgálatára volt lehetőség. Jelenlegi hosszú távú vizsgálatunk alapján megállapítható, hogy mindkét kezelési módszer esetében a klinikai paraméterek javulásának mértéke egyenrangúnak tűnik, az elért eredmények 7 év után is megtartottak.

Nickles és munkatársai retrospektív esetsorozatukban parodontális vertikális csontdefektusok zománcmátrix derivátumokkal történt ellátását követően 5 év elteltével szintén kedvező és hosszú távon fenntartható eredményekről számoltak be [13]. 

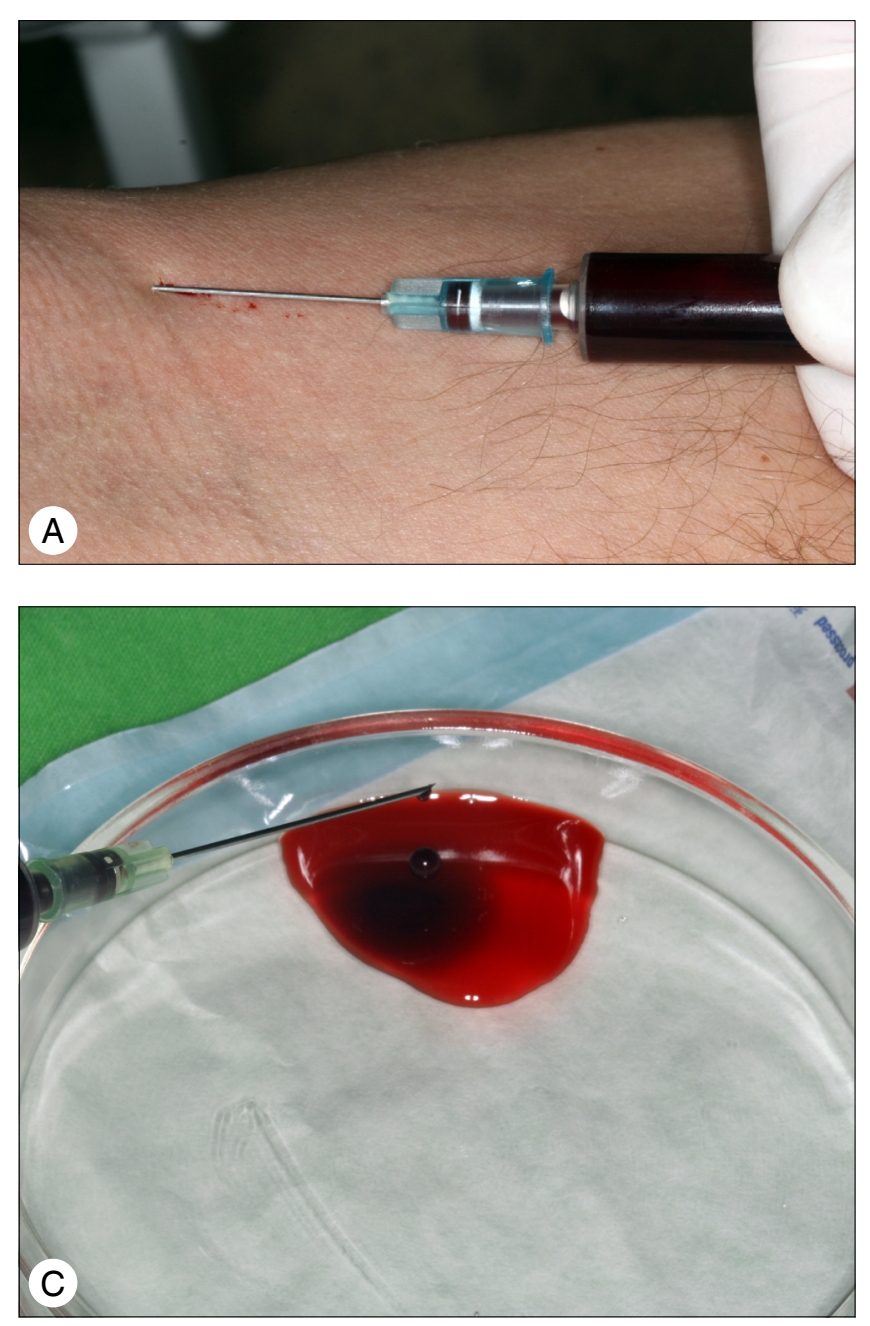

Kép 1: Vérlemezkében gazdag gél (PRG) előállítása (Prof. Dr. Döri F. mútéti anyaga):
A: Preoperatív vérvétel PRP preparáláshoz
$B$ : PRP és friss vénás vér
C: A PRG preparálása
$D$ : Elkészült PRG

Hasonló megfigyelések tapasztalhatók más korábbi hosszú távú követéses vizsgálatok adatai alapján is. Sculean és munkatársai több, parodontális intraosszeális defektus esetében végzett regeneratív célzatú beavatkozást követően, mind a zománc-mátrix derivátumok, mind az irányított szövetregenerációs technikák alkalmazása során, kiszámítható és fenntartható eredményekről számoltak be [15, 16, 17].

Kétségtelen, hogy a megfelelő plakk-kontroll nagymértékben hozzájárul a jó eredmények eléréséhez és ezek hosszú távú fenntartásához. A vizsgált paraméterek a bemutatott négy esetnél idővel hasonló változást mutattak, megerősítve a korábbi feltételezést, mely szerint a megfelelő szájhigiéné fenntartásával az elért eredmények hosszú távon megőrizhetőek. Úgy tûnik, hogy mindkét alkalmazott technika nemcsak az intraosszeális defektusok tekintetében hozott pozitív és tartós változást, hanem a szondázási mélység csökkenésével és
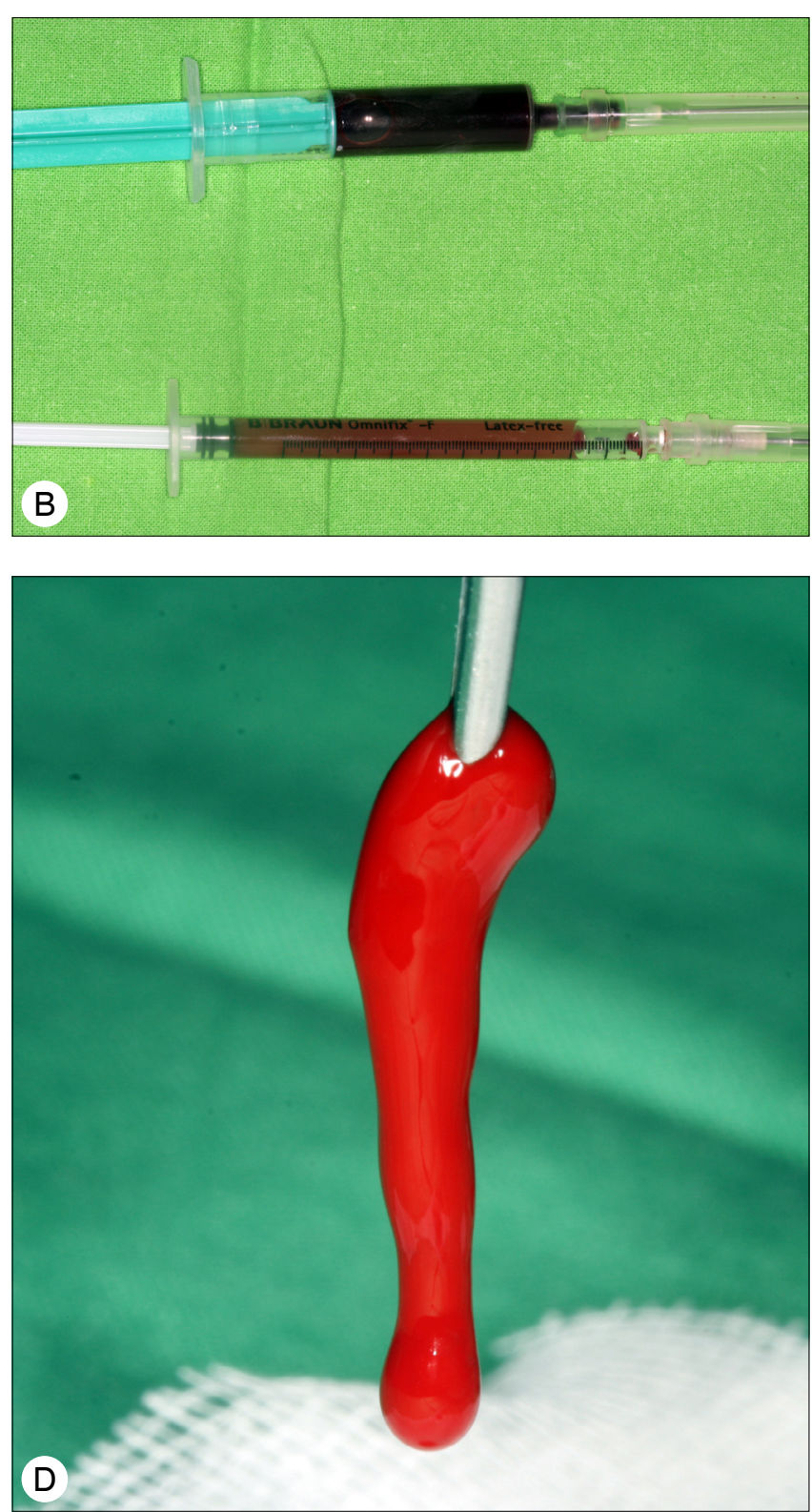

egy kedvező morfológia kialakításával nagymértékben hozzájárult a megfelelő plakk-kontroll hosszú távú fenntartásához.

Jelen vizsgálat megállapításainak értelmezésénél tekintettel kell lennünk arra, hogy tudomásunk szerint jelenleg nincs más tanulmány, amely közvetlen összehasonlítást lehetővé tenne.

Ugyanakkor több kontrollált vizsgálat számol be vérlemezkében gazdag plazma (PRP) és különböző graftokkal történt kombinációjával elért eredményekről, melyek meglehetősen ellentmondásosak [1, 3, 6, 8].

Sikert befolyásoló tényező lehet a PRP előállítására alkalmazott protokoll is. Ismert tény, hogy a különböző növekedési faktorok szintje vagy aránya eltérő lehet az alkalmazott rendszernek megfelelően [18].

Annak ellenére, hogy magasabb számú parodontális vertikális defektus gyógyulásának vizsgálatára lenne szükség a mútéti technikák közötti esetleges különbség ki- 

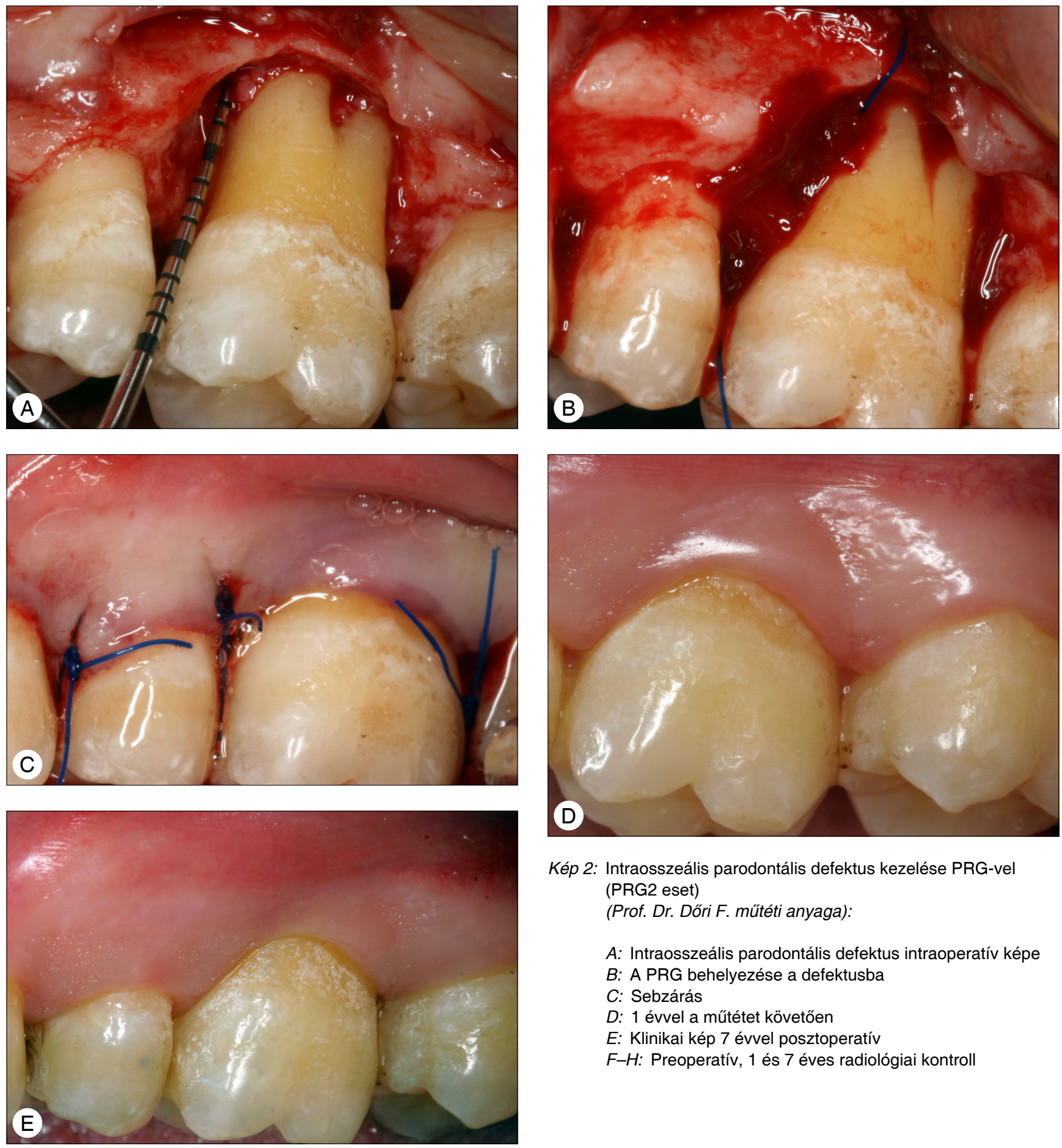

Kép 2: Intraosszeális parodontális defektus kezelése PRG-vel (PRG2 eset)

(Prof. Dr. Döri F. mútéti anyaga):

A: Intraosszeális parodontális defektus intraoperatív képe

$B$ : A PRG behelyezése a defektusba

C: Sebzárás

$D$ : 1 évvel a műtétet követően

E: Klinikai kép 7 évvel posztoperatív

$F-H$ : Preoperatív, 1 és 7 éves radiológiai kontroll
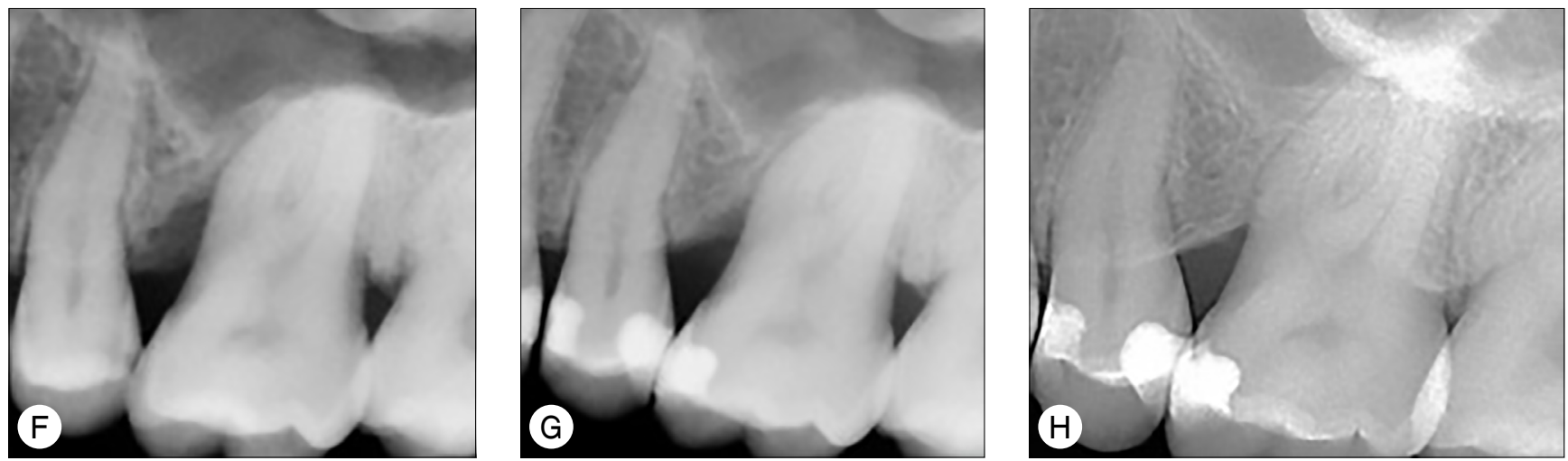

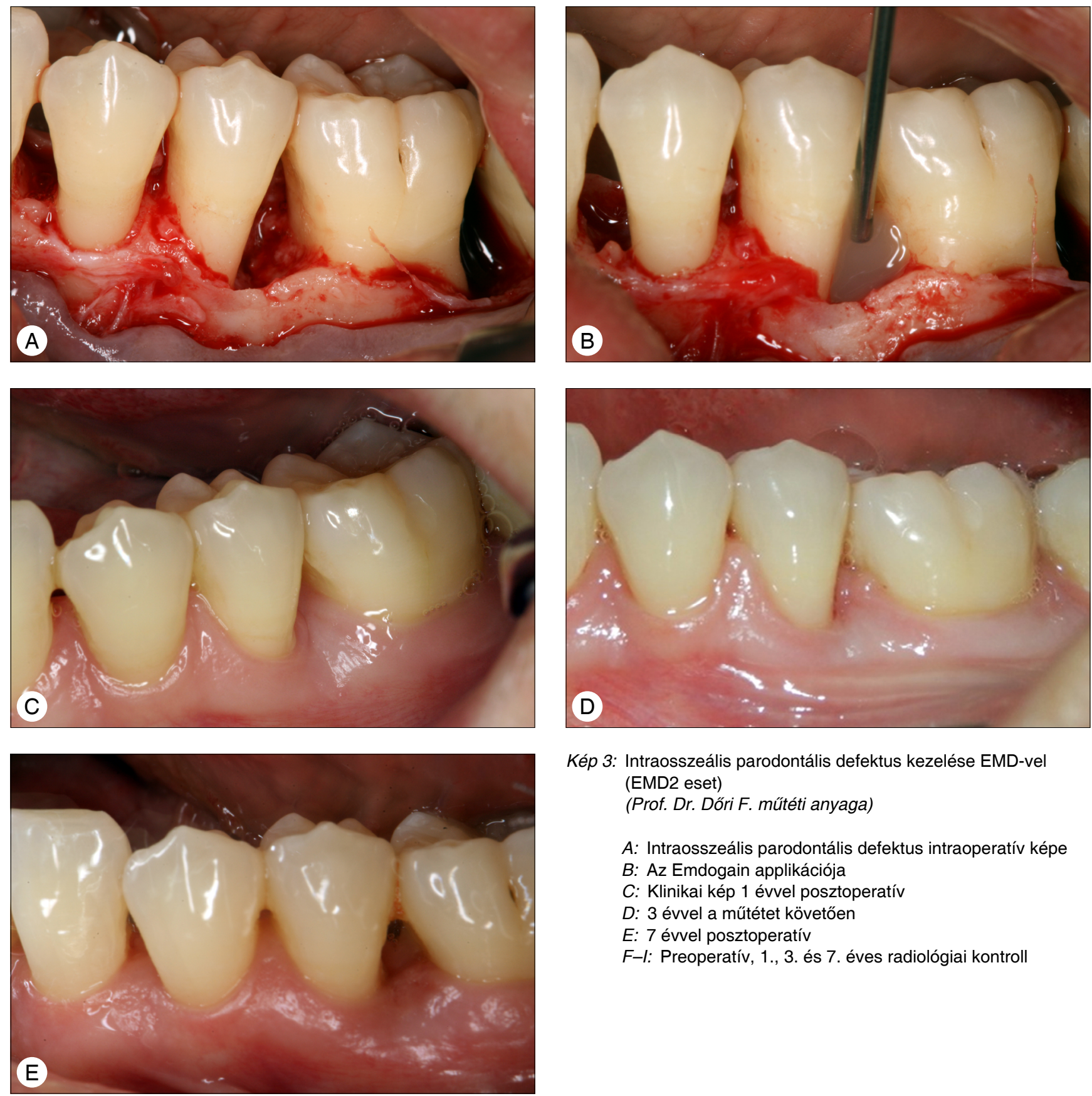

Kép 3: Intraosszeális parodontális defektus kezelése EMD-vel (EMD2 eset)

(Prof. Dr. Dőri F. mútéti anyaga)

A: Intraosszeális parodontális defektus intraoperatív képe

$B$ : Az Emdogain applikációja

C: Klinikai kép 1 évvel posztoperatív

$D$ : 3 évvel a mütétet követően

E: 7 évvel posztoperatív

F-I: Preoperatív, 1., 3. és 7. éves radiológiai kontroll
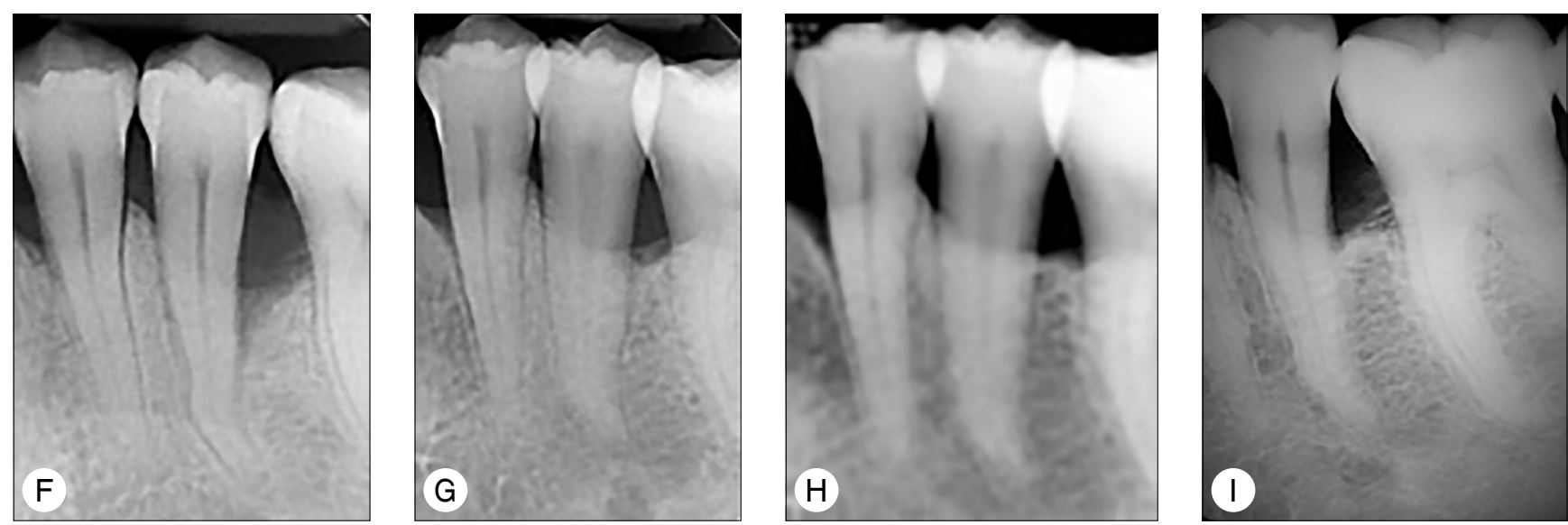
mutatásához, jelen adatok értékes információt nyújtanak a regeneratív célzatú technikák hosszabb távú hatékonyságáról. Továbbá, hosszú-távú eredmények kiértékelése során számos nehezítő körülmény adódhat, mely elsősorban a páciensek habitusának esetleges változásában és korlátozott elérhetőségében, valamint a nehézkes adminisztrációban mutatkozik meg. Öszszegzésképpen, a vizsgálat szűk keretein belül, megállapíthatjuk, hogy a klinikai eredmények mindkét vizsgált anyag esetében hosszabb távon is (7 év) fenntarthatóak voltak, PRG vagy EMD alkalmazásával megbízható klinikai eredményeket sikerült elérni.

Köszönetnyilvánítás: Köszönettel tartozom témavezetőmnek, Prof. Dr. Dőri Ferencnek nemcsak jelen tanulmány megírásához nyújtott támogató segítségéért, hanem PhD tanulmányaim során nyújtott útmutatásaiért és hasznos tanácsaiért is. Köszönöm a társszerzők segítségét, munkájuknak köszönhetően kerülhetnek bemutatásra az elért eredmények.

Anyagi támogatás: A közlemény megírása, illetve a kapcsolódó kutatómunka anyagi támogatásban nem részesült.

\section{Irodalom}

1. Camargo PM, Lekovic V, Weinlaender M, Divine-Resnik T, PAVLOVIC M, KenNeY EB: A surgical reentry study on the influence of platelet-rich plasma in enhancing the regenerative effects of bovine porous bone mineral and guided tissue regeneration in the treatment of intrabony defects in humans.

J Periodontol 2009 Jun; 80 (6): 915-923. PMID: 19485821 https://doi.org/10.1902/jop.2009.0806000

2. Döri F, Kovács V, Arweiler NB, Huszár T, Gera I, Sculean A: Effect of platelet-rich plasma on the healing of intrabony defects treated with an anorganic bovine bone mineral: a pilot study. J Periodontol 2009; 80 (10): 1599-1605. PMID: 19792848 https://doi.org/10.1902/jop.2009.090058

3. Döri F, Huszár T, Nikolidakis D, Arweiler NB, Gera I, Sculean A: Effect of platelet-rich plasma on the healing of intrabony defects treated with a natural bone mineral and a collagen membrane. J Clin Periodontol 2007; 34 (3): 254-261. PMID: 17257158 https://doi.org/10.1111/j.1600-051X.2006.01044.x

4. Döri F, Huszár T, Tihanyı D, Arweiler NB, Gera I, Sculean A: Healing of intrabony defects following treatment with PRG or EMD, J Dent Res Vol. 92: (Sp. Issue A) Paper 1606. (2013)

5. Döri F, Huszár T, Papp Zs, PILIHACI B, Tari N, BÁrsony N, Arweiler NB, Sculean A: Three Year Results Following Regenerative Surgery with PRG or EMD, 93th General Session of the IADR, 2015. Boston, USA, J Dent Res Vol. 94: Special Issue A (2015)

6. Dőri F, Huszár T, Nikolidakis D, Arweiler Nb, Gera I, Sculean A: Effect of platelet-rich plasma on the healing of intrabony defects treated with an anorganic bovine bone mineral and expanded polytetrafluoroethylene membranes.

J Periodontol 2007 Jun; 78 (6): 983-990. PMID: 17539709 https://doi.org/10.1902/jop.2007.060349
7. Gottlow J, Nyman S, Lindhe J, Karring T, Wennström J: New attachment formation in the human periodontium by guided tissue regeneration. Case reports. J Clin Periodontol 1986; 13 (6): 604-616. PMID: 3462208 https://doi.org/10.1111/j.1600-051X.1986.tb00854.x

8. Hanna R, Trejo PM, Weltman RL: Treatment of intrabony defects with bovine-derived xenograft alone and in combination with platelet-rich plasma: a randomized clinical trial. J Periodontol 2004 Dec; 75 (12): 1668-1677. PMID: 15732870 https://doi.org/10.1902/jop.2004.75.12.1668

9. HeiJl L, Heden G, Svardström G, Ostgren A: Enamel matrix derivative (EMDOGAIN) in the treatment of intrabony periodontal defects. J Clin Periodontol 1997; 24 (9 Pt 2): 705-714. PMID: 9310876 https://doi.org/10.1111/j.1600-051X.1997.tb00253.x

10. HEIJL L: Periodontal regeneration with enamel matrix derivative in one human experimental defect. A case report. J Clin Periodontol 1997.; 24 (9 Pt 2): 693-696. PMID: 9310874 https://doi.org/10.1034/j.1600-051X.1997.00693.x

11. MARX RE: Platelet-rich plasma: evidence to support its use. J Oral Maxillofac Surg 2004; 62 (4): 489-496. PMID: 15085519 https://doi.org/10.1016/j.joms.2003.12.003

12. Marx Re, Carlson ER, Eichstaest RM, Schimmel SR, Strauss Je, GeORGefF KR: Platelet-rich plasma:

Growth factor enhancement for bone grafts. Oral Surg Oral Med Oral Pathol Oral Radiol Endod 1998; 85 (6): 638-646. PMID: 9638695 https://doi.org/10.1016/S1079-2104(98)90029-4

13. Nickles K, Dannewitz B, Gallenbach K, Ramich T, Scharf S, Röllke L, Schacher B, EICKHOlz P: Long-Term Stability After Regenerative Treatment of Infrabony Defects: A Retrospective Case Series. J Periodontol 2017 Jun; 88 (6): 536-542. PMID: 28398116 https://doi.org/10.1902/jop.2017.160704

14. Sculean A, Windisch P, Dőri F, Keglevich T, Molnár B, Gera I: Emdogain in regenerative periodontal therapy. A review of the literature. Fogorvosi Szemle 2007; 100 (5): 220-232, 211-219. PMID: 18078142

15. Sculean A, Schwarz F, Miliauskaite $A$, et al: Treatment of intrabony defects with an enamel matrix protein derivative or bioabsorbable membrane: An 8-year follow-up split-mouth study. J Periodontol 2006; 77: 1879-1886. PMID: 17076614 https://doi.org/10.1902/jop.2006.060002

16. Sculean A, Schwarz F, Chiantella GC, Arweiler Nb, Becker J: Nine-year results following treatment of intrabony periodontal defects with an enamel matrix derivative: Report of 26 cases. Int J Periodontics Restorative Dent 2007; 27: 221-229. PMID: 17694945

17. Sculean A, Kiss A, Miliauskaite A, Schwarz F, Arweiler NB, HANNIG M: Ten-year results following treatment of intra-bony defects with enamel matrix proteins and guided tissue regeneration. J Clin Periodontol 2008; 35: 817-824. PMID: 18647201 https://doi.org/10.1111/j.1600-051X.2008.01295.X

18. Weibrich G, LeIS WK, HafNER G: Growth factor levels in the platelet-rich plasma pro-duced by 2 different methods: Curasan-type PRP kit versus PCCS PRP system. Int J Oral Maxillofac Implants 2002; 17: 184-190. PMID: 11958400

19. Werther K, Christensen IJ, Nielsen HJ: Determination of vascular endothelial growth factor (VEGF) in circulating blood: significance of VEGF in various leucocytes and plate-lets. Scand J Clin Lab Invest 2002; 62: 343-350. PMID: 12387579 https://doi.org/10.1080/00365510260296492 
CSIFó-NAgy B, Sólyom E, Huszár T, Dőri F

\section{Healing of intrabony defects following treatment with PRG or EMD (seven years follow-up)}

A retrospective case series

Introduction: The aim of this retrospective case series was to clinically evaluate the long-term healing of intrabony defects after treatment with an autologous platelet-rich gel (PRG) to enamel matrix derivatives (EMD).

Case report: The presented cases are part of a controlled trial where 24 non-smoking patients with intrabony defects were treated with PRG or EMD. Evaluations were made after 1 and 3 years. In 4 cases the following parameters were assessed at baseline and 1 year, 3 years, and 7 years postoperatively: pocket depth (PD), clinical attachment level (CAL). After full flap preparation, defect curettage, scaling and root planing were performed. First platelet-rich plasma (PRP) was prepared, then the addition of Ca-gluconate and fresh venous blood resulted in platelet-rich gel (PRG) formation. The intrabony defects were filled with PRG $(n=2)$ or EMD $(n=2)$ and fixed with sutures to ensure wound closure and stability.

Results: By sites treated with PRG the following changes can be observed: probing depth reduction from 9 to 5 $\mathrm{mm}$, CAL changed from 10 to $5 \mathrm{~mm}$ in the first case and both parameters changed from 10 to $6 \mathrm{~mm}$ in the second case (7 years). Significant improvement has also been noted by sites treated with EMD: PD reduction from 11 to $3 \mathrm{~mm}, \mathrm{CAL}$ changed from 11 to $5 \mathrm{~mm}$ in the first case and from 9 to $4 \mathrm{~mm}$, CAL from 10 to $4 \mathrm{~mm}$ in the second case (7 years).

Conclusion: One year after surgery, both treatment methods resulted in significant PD reductions and CAL gains, and these results were stable after 7 years. No significant difference was observed between the 1 year, 3 years, and 7 years values. Treatment with PRG or EMD resulted in reliable clinical outcomes.

Keywords: intrabony defects, platelet-rich gel, enamel matrix derivatives, periodontal regeneration, long term follow-up 